\title{
Penerapan Metode Course Review Horay dengan Multimedia dalam Peningkatan Pembelajaran IPS tentang Peninggalan Sejarah pada Siswa Kelas IV SDN Sumberadi Tahun Ajaran 2015/2016
}

\author{
Nur Sangadah ${ }^{1}$, Wahyudi², Tri Saptuti Susiani ${ }^{3}$ \\ 1,2,3Universitas Sebelas Maret \\ nurs60@gmail.com
}

\section{Article History}

accepted 01/06/2019

\begin{abstract}
The objectives of this research was to describe steps on the application of Course Review Horay method using multimedia and to improve social science learning about historical heritage. This research is a Classroom Action Research (CAR) conducted within three cycles. Subjects of the research were 32 students of the fourth grade of SDN Sumberadi. Source of data were derived from students, teacher, observer, and document. The conclusion of this research is the application of Course Review Horay method using multimedia can improve social science learning about the historical heritage for the fourth grade students of SDN Sumberadi in the academic year of 2015/2016.
\end{abstract}

Keywords: Course Review Horay, multimedia, social science

\section{Abstrak}

Tujuan penelitian ini adalah mendeskripsikan langkah-langkah penerapan metode Course Review Horay dengan multimedia dan meningkatkan pembelajaran IPS tentang peninggalan sejarah. Penelitian ini merupakan penelitian tindakan kelas yang dilaksanakan dalam tiga siklus. Subjek penelitian ini adalah siswa kelas IV SDN Sumberadi yang berjumlah 32 siswa. Sumber datanya adalah siswa, guru, observer, dan dokumen. Kesimpulan dari hasil penelitian ini adalah penerapan metode Course Review Horay dengan multimedia dapat meningkatkan pembelajaran IPS tentang peninggalan sejarah pada siswa kelas IV SDN Sumberadi Tahun Ajaran 2015/2016.

Kata kunci: Course Review Horay, multimedia, IPS 


\section{PENDAHULUAN}

Melalui pengajaran IPS siswa dapat memperoleh pengetahuan, keterampilan, sikap, dan kepekaan untuk menghadapi hidup dengan tantangan-tantangannya (Hidayati, Mujinem, dan Anwar Senen, 2008: 1.12). Ruang lingkup IPS sangat beragam, seperti ekonomi, sejarah, sosiologi, antropologi, dan geografi.

Berdasarkan observasi dan wawancara terhadap siswa kelas IV di SDN Sumberadi diketahui bahwa pada saat proses pembelajaran: 1) siswa masih bermain sendiri, 2) siswa mengganggu temannya, 3) siswa membuat gaduh, 4) siswa mengobrol dengan teman sebangkunya ketika guru menjelaskan materi, 5) siswa takut untuk bertanya hal yang belum dipahami kepada guru, 6) siswa tidak suka berkelompok jika terdapat siswa laki-laki dan perempuan dalam kelompok yang sama, 7) siswa membeda-bedakan teman ketika berkelompok, 8) siswa tidak tenang dalam mengerjakan soal evaluasi karena siswa berusaha memperoleh jawaban dengan bertanya pada teman. Keadaan ini menunjukkan bahwa kondisi siswa sudah aktif tetapi aktif yang belum terarah hal ini berdasarkan data nomor 1, 2, 3, dan 4. Pada data nomor 5 , siswa belum memiliki keberanian untuk bertanya sehingga siswa kurang paham terhapat materi yang diberikan guru. Sesuai dengan data nomor 6 dan 7, kerja sama antarsiswa masih terlihat kurang karena belum mampu bekerja sama dengan semua teman. Sedangkan pada data nomor 8 , siswa masih kurang bertanggung jawab terhadap tugas yang telah diberikan.

Berdasarkan data yang didapat peneliti, diketahui bahwa proses pembelajaran di SDN Sumberadi kelas IV belum dilaksanakan secara optimal. Hal ini juga terbukti dengan hasil nilai Ulangan Tengah Semester (UTS) mata pelajaran IPS pada semester ganjil tahun ajaran 2014/2015 untuk tema Indahnya Kebersamaan dan Selalu Berhemat Energi masih rendah dan masih banyak yang belum memenuhi Kriteria Ketuntasan Minimal (KKM) yang ditetapkan sekolah yaitu 68. Nilai rata-rata kelas hanya mencapai 60,13 . Dari 38 siswa kelas IV hanya 14 siswa (37\%) yang sudah tuntas. Sedangkan yang mendapat nilai kurang dari 68 sebanyak 24 siswa (63\%) dengan kriteria belum tuntas.

Peran dan keberadaan guru sangat penting dalam proses pembelajaran. Guru berperan sebagai pembimbing dan fasilitator sehingga proses pembelajaran dapat berlangsung dengan mengutamakan keaktifan peserta didik. Kebanyakan guru mengajar masih konvensional, misalnya penggunaan metode ceramah, tanya jawab, dan penugasan sehingga pemahaman siswa masih kurang. Pembelajaran yang konvensional saja tidak dapat memfasilitasi siswa untuk mengungkapkan ide, kreativitas serta keaktifan siswa dalam pembelajaran secara maksimal. Penggunaan media yang tepat dalam pembelajaran juga dapat membantu pemahaman siswa.

Berdasarkan uraian tersebut, maka peneliti bermaksud melaksanakan penelitian tindakan kelas yang berkolaborasi dengan guru kelas untuk meningkatkan pembelajaran IPS kelas IV.

Metode pengajaran yang digunakan guru tidak ada yang sia-sia karena suatu metode akan mendatangkan hasil, baik dalam waktu yang dekat maupun dalam waktu yang relatif lama. Menurut Huda (2013: 229-230) Course Review Horay merupakan metode pembelajaran yang dapat menciptakan suasana kelas menjadi meriah dan menyenangkan karena setiap siswa yang dapat menjawab benar diwajibkan berteriak 'horee!!' atau yel-yel lainnya yang disukai.

Selain metode, pemilihan media juga dapat membantu pemahaman siswa dalam pembelajaran. Salah satunya dengan menggunakan multimedia. Pada saat ini telah berkembang berbagai jenis multimedia. Anitah (2010: 56) menjelaskan multimedia sebagai penggunaan berbagai jenis media secara berurutan maupun simultan untuk menyajikan suatu informasi. Smaldino (dalam Anitah, 2010: 56) juga mengungkapkan bahwa multimedia tidak harus menggunakan alat-alat canggih. Menurut Rusman (2012: 150) mengartikan multimedia sebagai penggunaan beberapa 
media yang berbeda untuk menggabungkan dan menyampaikan informasi dalam bentuk text, audio, grafis, animasi, dan video.

Berdasarkan uraian tersebut rumusan masalah pada penelitian ini adalah bagaimana penerapan metode Course Review Horay dengan multimedia dalam pembelajaran dan apakah penerapan metode Course Review Horay dengan multimedia dapat meningkatkan pembelajaran IPS tentang Peninggalan Sejarah pada siswa kelas IV SDN Sumberadi Tahun Ajaran 2015/2016?

Tujuan penelitian ini adalah mendeskripsikan langkah-langkah penerapan metode Course Review Horay dengan multimedia dan meningkatkan pembelajaran IPS tentang Peninggalan Sejarah pada siswa kelas IV SDN Sumberadi Tahun Ajaran 2015/2016.

\section{METODE}

Penelitian tindakan kelas ini dilaksanakan di SD Negeri Sumberadi pada bulan November dan Desember 2015 dengan subjek siswa Kelas IV SD Negeri Sumberadi Tahun Ajaran 2015/2016 yang berjumlah 32 siswa dengan rincian 12 siswa laki-laki dan 20 siswa perempuan.

Data yang diperoleh bersumber dari guru dan siswa kelas IV. Teknik pengumpulan data yang digunakan adalah tes (nilai hasil belajar) dan nontes (observasi dan wawancara). Data yang diperoleh berupa data kuantitatif (nilai hasil belajar dan skor observasi) dan kualitatif (informasi dan deskripsi proses belajar). Validitas data diuji menggunakan teknik triangulasi sumber dan alat pengumpulan data. Kemudian data dianalisis menggunakan pendapat Miles dan Huberman yang meliputi reduksi data, penyajian data, dan penarikan keimpulan (dalam Sugiyono, 2013: 337-345).

Indikator kinerja penelitian yang ditargetkan adalah 85\% untuk penerapan metode Course Review Horay dengan multimedia dalam pembelajaran IPS dan respon siswa serta ketuntasan pembelajaran melalui tes hasil belajar siswa dengan KKM $\geq 70$ sebesar $85 \%$. Prosedur penelitian tindakan ini meliputi empat tahapan yaitu perencanaan, pelaksanaan, observasi, dan refleksi (Arikunto, S., Suhardjono, dan Supardi, 2012: 17).

\section{HASIL DAN PEMBAHASAN}

Pelaksanaan tindakan ini dilak-sanakan selama 3 siklus. Setiap siklus meliputi 2 pertemuan. Penelitian tin-dakan menggunakan langkah-langkah penerapan metode Course Review Horay dengan multimedia yaitu: (1) guru menyampaikan kompetensi yang ingin dicapai, (2) guru membagikan Lembar Kerja Siswa (LKS) dan menyajikan materi sesuai topik menggunakan multimedia, (3) guru memberi kesempatan pada siswa untuk bertanya, (4) guru membagi siswa dalam beberapa kelompok dan membagikan lembar diskusi yang berisi kotak dengan nomor yang telah ditentukan, (5) guru membaca soal secara acak dan siswa menuliskan jawabannya di dalam kotak sesuai nomor yang ditentukan, (6) guru bersama siswa mendiskusikan soal yang telah diberikan sebelumnya, jika pertanyaan dijawab dengan benar maka guru memberi tanda check list $(\sqrt{ })$ dan siswa langsung berteriak 'horee!!' atau menyanyikan yelyelnya, jika salah guru memberi tanda silang $(X)$, (7) nilai siswa dihitung dari jawaban yang benar, (8) guru memberikan reward pada kelompok yang memperoleh nilai tertinggi, (9) penutup.

Data hasil observasi penerapan metode Course Review Horay dengan multimedia oleh guru dan siswa pada siklus I, II dan III sebagai berikut: 
Tabel1. Hasil Observasi Penerapan Metode Course Review Horay dengan Multimedia

\begin{tabular}{llcc}
\hline & & Guru & Siswa \\
\hline Siklus I & Rata-Rata & 3,35 & 3,12 \\
\hline & Presentase & 83,67 & 78,00 \\
\hline Siklus II & Rata-Rata & 3,73 & 3,57 \\
\hline & Presentase & 93,33 & 89,33 \\
\hline Siklus III & Rata-Rata & 3,91 & 3,75 \\
\hline & Presentase & 97,83 & 93,83 \\
\hline
\end{tabular}

Berdasarkan tabel 1, dapat disi-mpulkan bahwa hasil rata-rata observa-si guru pada siklus I sebesar 3,35 atau $83,67 \%$ dan pada siklus II mengalami peningkatan menjadi 3,73 atau $93,33 \%$, pada siklus III meningkat menjadi 3,91 atau $97,83 \%$ sehingga sudah mencapai hasil yang sangat baik dan optimal.

Hasil observasi terhadap siswa pada siklus I sebesar 3,12 atau $78 \%$, pada siklus II mengalami peningkatan menjadi 3,57 atau $89,33 \%$ dan pada siklus III menjadi 3,75 atau $93,83 \%$, artinya sudah memenuhi indikator kinerja yaitu $85 \%$. Berdasarkan data tersebut dapat diketahui bahwa telah terjadi peningkatan yang sangat baik dan pada siklus III sudah menunjukkan hasil yang optimal.

Selain proses pembelajaran ya-ng dilaksanakan guru dan siswa dengan menerapkan metode Course Review Horay dengan multimedia berikut disajikan perbandingan kentutasan hasil belajar tes tertulis siswa pada siklus I, II, dan III.

Tabel 2. Perbandingan Ketuntasan Hasil Belajar Siswa pada Siklus I-III

\begin{tabular}{lcc}
\hline & \multicolumn{2}{c}{$\begin{array}{c}\text { Ketuntasan Hasil } \\
\text { Belajar }\end{array}$} \\
\cline { 2 - 3 } & Tuntas & $\begin{array}{c}\text { Belum } \\
\text { Tuntas }\end{array}$ \\
\hline Siklus 1 & $71,88 \%$ & $28,12 \%$ \\
Siklus 2 & $85,94 \%$ & $14,06 \%$ \\
Siklus 3 & $95,31 \%$ & $4,69 \%$ \\
\hline
\end{tabular}

Berdasarkan tabel 2, dapat dili-hat bahwa ketuntasan hasil belajar sis-wa selalu mengalami peningkatan pada setiap siklus. Pada siklus I presentase ketuntasan hasil belajar siswa yaitu $71,88 \%$, pada siklus II mengalami pe-ningkatan menjadi $85,94 \%$ dan pada siklus III mengalami peningkatan men-jadi 95,31\%, merupakan hasil yang sangat baik serta telah memenuhi indi-kator kinerja yaitu $85 \%$ sehingga peneliti mengakhiri penelitian tindakan kelas ini.

\section{SIMPULAN}

Berdasarkan hasil penelitian diperoleh beberapa kesimpulan sebagai berikut:

1. Langkah-langkah penerapan metode Course Review Horay dengan multimedia dalam peningkatan pembelajaran IPS pada siswa kelas IV SD Negeri Sumberadi Tahun Ajaran 2015/2016 dilakukan melalui 9 langkah. Langkah-langkah Course Review Horay dengan multimedia yaitu: (1) penyampaian kompetensi, (2) pembagian LKS dan penyajian materi dengan multimedia, (3) bertanya, (4) pembagian kelompok dan lembar diskusi, (5) pembacaan soal, (6) diskusi soal, (7) penghitungan nilai, (8) pemberian reward, (9) penutup. Penerapan pembelajaran oleh guru meningkat dari $83,67 \%$ pada siklus I, menjadi $93,33 \%$ pada siklus II, dan $97,83 \%$ pada siklus III.

2. Penerapan metode Course Review Horay dengan multimedia dapat meningkatkan pembelajaran IPS tentang peninggalan sejarah pada siswa kelas IV SD Negeri Sumberadi Tahun Ajaran 2015/2016. Hal itu dibuktikan dengan peningkatan respon 


\section{Volume 7 Nomor 2 Tahun 2019}

belajar siswa dari $78,00 \%$ pada siklus I, menjadi $89,33 \%$ pada siklus II, dan $93,83 \%$ pada siklus III. Ketuntasan hasil belajar siswa meningkat dari $71,88 \%$ pada siklus I, menjadi $85,94 \%$ pada siklus II, dan $95,31 \%$ pada siklus III.

Implikasi dari penelitian ini yaitu, implikasi secara teoretis yang membe-rikan gambaran bahwa penerapan metode Course Review Horay dengan multimedia dapat meningkatkan pembelajaran. Sedangkan implikasi praktisnya adalah membuat siswa merasa senang dan tidak cepat bosan dalam mengikuti pembelajaran.

Peneliti memberikan beberapa saran sebagai berikut: (1) Bagi siswa, hendaknya siswa lebih meningkatkan minat belajar karena sangat berpengaruh terhadap proses dan hasil belajar, terutaman pada mata pelajaran IPS, (2) Bagi guru, guru hendaknya menerapkan setiap metode pembelajaran seperti metode Course Review Horay dengan multimedia dilaksanakan sesuai langkah-langkahnya, (3) Bagi sekolah, mendukung dan menfasilitasi guru dalam melaksanakan pembelajaran yang inovatif, seperti menerapkan metode Course Review Horay dengan multimedia, (4) Bagi peneliti lain, dapat dijadikan sebagai referensi tentang pelaksanaan pembelajaran IPS dengan menggunakan metode Course Review Horay dengan multimedia.

\section{DAFTAR PUSTAKA}

Anitah, S. (2010). Media Pembelajaran. Surakarta: Yuma Pustaka.

Arikunto, S., Suhardjono, dan Supardi. (2012). Penelitian Tindakan Kelas. Jakarta: PT Bumi Aksara.

Hidayati, Mujinem, dan Anwar Senen. (2008). Pengembangan Pendidikan IPS SD. Jakarta: Depdiknas.

Huda, M. (2013). Model-Model Pengajaran dan Pembelajaran. Yogyakarta: Pustaka Pelajar.

Rusman. (2012). Belajar dan pembelajaran Berbasis Komputer Mengembangkan Profesionalisme Abad 21. Bandung: Alfabeta.

Sugiyono. (2013). Metode Penelitian Pendidikan (Pendekatan Kuantitatif, Kualitatif, dan $R \& D$ ). Bandung: Alfabeta. 